\title{
Crop coefficients of tropical forage crops, single cropped and overseeded with black oat
} and ryegrass

\author{
Arthur Carniato Sanches ${ }^{* *(0)}$, Débora Pantojo de Souza ${ }^{2}$, Fernanda Lamede Ferreira de Jesus ${ }^{2}\left(\mathbb{0}\right.$, Fernando Campos Mendonça ${ }^{2}$, \\ Eder Pereira Gomes ${ }^{1}$ (1)
}

'Universidade Federal de Grande Dourados/Faculdade de Ciências Agrárias, Rod. Dourados/Itahum, km 12 - 79804970 - Dourados, MS - Brasil.

2Universidade de São Paulo/ESALQ - Depto. de Engenharia Biossistemas, Av. Pádua Dias, 11 - 13418-900 - Piracicaba, $\mathrm{SP}$ - Brasil.

*Corresponding author <ArthurSanches@ufgd.edu.br>

Edited by: Mohammad Valipour

Received November 12, 2017

Accepted June 26, 2018
ABSTRACT: Crop coefficient $(\mathrm{Kc})$ is the ratio between crop evapotranspiration $(\mathrm{ETC})$ and reference evapotranspiration (ETo), representing the phenological effects on crop water consumption. $\mathrm{Kc}$ is fundamental to estimating ETc by agrometeorological methods. This research study aimed to determine $\mathrm{Kc}$ and ETc values for Guinea grass (Megathyrsus maximus cv. Mombaça) and Bermuda grass (Cynodon spp.), both single cropped for one year and overseeded with black oat (Avena strigosa) and ryegrass (Lolium multiflorum) during fall/winter. The experiment in the field comprised four plots, two for each tropical forage, with and without overseeding. At the center of each plot, there was a weighing lysimeter with an automated system for data collection. ETc was measured daily over four seasons following the lysimetric method; ETo was calculated using the Penman-Monteith equation. ETc and ETo values were used to estimate $\mathrm{Kc}$ values. The single cropped Guinea grass showed the highest values for ETc, with mean ETc and $\mathrm{Kc}$ of $3.99 \mathrm{~mm} \mathrm{~d}^{-1}$ and 1.07 , respectively. The single cropped Bermuda grass showed ETc and $\mathrm{Kc}$ values of $3.57 \mathrm{~mm} \mathrm{~d}^{-1}$ and 0.96 , respectively. The results of paired t-testing for Kc showed no significant differences $(p=0.05)$ between single cropped and intercropped for both Guinea grass and Cynodon spp. During winter, intercropped Guinea grass did not show an ETc signifcantly higher than single cropped Guinea grass, with mean $\mathrm{Kc}$ values 0.98 for intercropped and 1.10 for single cropped. Similarly, Bermuda grass did not show significant differences between mean Kc values for intercropped (1.02) and single cropped (1.00).

Keywords: Avena strigosa, Lolium multiflorum, evapotranspiration, lysimetry, tropical pastures

\section{Introduction}

Livestock and agriculture have been engaging in a competing claim for land in Brazil. Therefore, cattle ranchers must increase their adoption of technologies to raise soil fertility levels and to use irrigation, with the aim of enhancing both the animal stock rate per area and production efficiency (Barbosa et al., 2015). The pasture forage yield is high during the warm, rainy season and low during drought periods or in the cold, dry season. The reduced forage yield during the dry season is defined as production seasonality (Antoniel et al., 2016; Durante et al., 2017). The main factors that affect tropical forage yield are soil water content, solar radiation, photoperiod and temperature (Barbosa et al., 2015). If the last three factors are not a hindrance, irrigation can overcome the soil water deficit and increase the forage yield (Neal et al., 2011).

In spite of technological advances in water supply, irrigation management is still inefficient in most areas. The lack of information on crop water needs is one of the main causes of inefficient water use (Marin et al., 2016). Crop water consumption, known as crop evapotranspiration (ETc), depends directly on atmospheric energy demand, the soil water content and plant resistance to losing water to the atmosphere (Pereira et al., 2015).

The methods commonly used for estimating crop evapotranspiration (ETc) are based on soil water balance, eddy covariance and energy balance (Zhang et al., 2008). One of the methods of soil water balance is the use of a lysimeter (Allen et al., 2011a), which consists of a tank, that allows for calculating variations in the soil water content inside the device, from differences between water inputs and outputs (drainage lysimeters) or from variations in weight (weighing lysimeters) (Bilibio et al., 2017). With the ETc and estimation of reference evapotranspiration (ETo) (Allen et al., 1998), it is possible to determine values for the crop coefficient $(\mathrm{Kc})$. Given the Kc values and ETo, it is possible to estimate ETc from meteorological data (Zheng et al., 2012).

Some research studies have shown that ETc of pasture forage crops have Kc values higher than 1 (Barbosa et al., 2015; Antoniel et al., 2016; Santana et al., 2016; Sanches et al., 2017b). Sanches et al. (2017b) studied three genera of grasses, Megathyrsus, Brachiaria and Cynodon, and observed a large amplitude of $\mathrm{Kc}$, reaching a value of up to 1.7 for Megathyrsus maximum cv. Mombaça. Up to the present time, there are few studies on Kc for tropical forages, and no studies on Kc values for tropical forage intercropped with winter forage crops. Thus, this work aimed to obtain Kc for two tropical forage crops (Guinea grass and Bermuda grass) single cropped throughout the year and overseeded with black oat and ryegrass during the fall/winter season.

\section{Materials and Methods}

The work was conducted in an experimental area in the municipality of Piracicaba, in the state of São Pau- 
lo, Brazil (Latitude $22^{\circ} 42^{\prime} 14.6^{\prime \prime}$ S; Longitude $47^{\circ} 37^{\prime} 24.1^{\prime \prime}$ W; 569 m a.s.l.), from Feb 2016 to Feb 2017, with data collection over the course of the four climatic seasons of the year.

According to Köppen's climate classification, the local weather is Cwa-humid subtropical climate or altitude tropical climate with hot summers; a coldest month's average temperature above $0{ }^{\circ} \mathrm{C}$ and hottest month's average temperature above $22^{\circ} \mathrm{C}$, with rainfall concentrated in the summer months (Alvares et al., 2013). The soil in the region is classified as Clayey Oxisol ('Nitossolo Vermelho Eutroférrico Latossólico' in Brazilian classification) (Weil and Brady, 2016), whose textural analysis shows $49 \%$ clay, $32 \%$ silt and $19 \%$ sand (Table 1 ).

The forages used in the work were Guinea grass (Megathyrsus maximus cv. Mombaça) and Bermuda grass (Cynodon spp.), single cropped throughout the year and intercropped with black oat (Avena strigosa cv. Embrapa 29 Garoa) and ryegrass (Lolium multiflorum cv. Fepagro São Gabriel) during the fall/winter seasons. The experiment was carried out on four $12 \times 12 \mathrm{~m}$ experimental plots, each one with a weighing lysimeter in the center. The plots were cultivated as follows: Plot 1: Guinea grass, 12 Feb 2016 - 13 Feb 2017, 12 collection cycles or cut cycle (12 CC); Plot 2: Guinea grass + black oat + ryegrass, 5 July 2016 - 9 Sept 2016 (4 CC); Plot 3: Bermuda grass, 2 Feb 2016 - 2 Feb 2017 (14 CC); and Plot 4: Bermuda grass + black oat + ryegrass, 30 Apr 2016 - 14 Oct 2016 (6 CC), as presented in Table 2 . Tropical forages used in pastures grow rapidly. Consequently, there were several forage cutting cycles throughout the year. These cycles varied from 21 to 40 days, depending on the climate elements (temperature, radiation, rainfall) and the pasture genus.

Glyphosate was applied twice at the beginning of the experiment, in order to avoid weed infestation until the forages had been established. Pastures were implanted on different dates, planting Bermuda grass seedlings on 16 Nov 2015, and sowing Guinea grass on 29 Nov 2015. As shown in Table 2, black oats and ryegrass were sown on $30 \mathrm{Apr}$ and 7 May, in the Bermuda and Guinea grass plots, respectively. In each growth cycle, dry matter yield $\left(\mathrm{DM}, \mathrm{kg} \mathrm{ha}^{-1}\right)$ and leaf area (LAI) index were quantified. A square sampler $\left(0.25 \mathrm{~m}^{2}\right)$ was thrown at random four times into each experimental plot; the forage in the sampler was cut, up to the pre-established height of the residue $(0.3 \mathrm{~m}$ for Guinea grass 'Mombaça' and $0.1 \mathrm{~m}$ for Bermuda grass Cynodon spp.). Living and dead material were separated and put into a forced airventilated oven $\left(65^{\circ} \mathrm{C}, 72 \mathrm{~h}\right)$, to calculate DM. Throughout the experimental period, LAI measurements were taken every three days, for Cynodon spp., and every four days for 'Mombaça' Guinea grass, respectively, using leaf-area integrator equipment. At the end of each growth cycle, we took forage samples to evaluate growth and LAI, with another unit of leaf-area integrator equipment (destructive method), in order to verify the field method. Thus, we evaluated the evolution of Kc related to the development of the plants, with use and indica-

Table 1 - Chemical and granulometric analysis of the soil of the experimental area in the 0-20 cm and 20-40 cm layers (Piracicaba city 2015).

\begin{tabular}{|c|c|c|c|c|c|c|c|c|c|c|c|}
\hline Layer & $\mathrm{pH}$ & $\mathrm{P}$ & $K$ & $\mathrm{Ca}$ & $\mathrm{Mg}$ & $\mathrm{H}+\mathrm{Al}$ & Al & CEC & Sand & Silt & Clay \\
\hline $\mathrm{cm}$ & $\mathrm{CaCl}_{2}$ & $\mathrm{mg} \mathrm{dm}^{-3}$ & & & $-c$ & $\mathrm{~m}^{-3}$ & & & & $-\%$ & \\
\hline $0-20$ & 5.3 & 72 & 0.9 & 3.9 & 1.8 & 3.1 & 0.2 & 9.74 & 35.7 & 19.2 & 45.1 \\
\hline $20-40$ & 4.9 & 31 & 0.4 & 1.3 & 1.0 & 4.2 & 0.2 & 6.94 & 29.3 & 18.7 & 52.0 \\
\hline
\end{tabular}

$\mathrm{P}=$ phosphorus $; \mathrm{K}=$ potassium; $\mathrm{Ca}=$ calcium; $\mathrm{Mg}=$ magnesium; $\mathrm{H}+\mathrm{Al}$ = potential acidity; $\mathrm{Al}=$ exchangeable aluminum; $\mathrm{CEC}=$ cation exchange complex.

Table 2 - Dates and periods of cuts of the exclusive and overseeded weeds during the experimental period. Piracicaba/SP, 2016-2017.

\begin{tabular}{|c|c|c|c|c|}
\hline \multirow{2}{*}{$\mathrm{CC}$} & Plot 1 & Plot 2 & Plot 3 & Plot 4 \\
\hline & \multicolumn{4}{|c|}{ Period (days of cycle interval - START to END) } \\
\hline $1^{\text {st }}$ & $12 / 02$ to $11 / 03 / 2016$ & - & $19 / 02$ to $18 / 03 / 2016$ & - \\
\hline $2^{\text {nd }}$ & $12 / 03$ to $08 / 04 / 2016$ & - & $19 / 03$ to $08 / 04 / 2016$ & - \\
\hline $3^{\text {rd }}$ & $09 / 04$ to $06 / 05 / 2016$ & - & $09 / 04$ to $29 / 04 / 2016$ & - \\
\hline $4^{\text {th }}$ * & $07 / 05$ to $15 / 06 / 2016$ & $07 / 05$ to $15 / 06 / 2016$ & $30 / 04$ to $01 / 06 / 2016$ & $30 / 04$ to $01 / 06 / 2016$ \\
\hline $5^{\text {th }}$ & $16 / 06$ to $25 / 07 / 2016$ & $16 / 06$ to $21 / 07 / 2016$ & $02 / 06$ to $01 / 07 / 2016$ & $02 / 06$ to $28 / 06 / 2016$ \\
\hline $6^{\text {th }}$ & $26 / 07$ to $03 / 09 / 2016$ & $22 / 07$ to $22 / 08 / 2016$ & $02 / 07$ to $06 / 08 / 2016$ & $29 / 06$ to $22 / 07 / 2016$ \\
\hline $7^{\text {th }}$ & $04 / 09$ to $01 / 10 / 2016$ & $23 / 08$ to $23 / 09 / 2016$ & $07 / 08$ to $08 / 09 / 2016$ & $23 / 07$ to $12 / 08 / 2016$ \\
\hline $8^{\text {th }}$ & $02 / 10$ to $29 / 10 / 2016$ & - & $09 / 09$ to $11 / 10 / 2016$ & $13 / 08$ to $08 / 09 / 2016$ \\
\hline $9^{\text {th }}$ & $30 / 10$ to $25 / 11 / 2016$ & - & $12 / 10$ to $01 / 11 / 2016$ & $09 / 09$ to $14 / 10 / 2016$ \\
\hline $10^{\text {th }}$ & $26 / 11$ to $19 / 12 / 2016$ & - & $02 / 11$ to $22 / 11 / 2016$ & - \\
\hline $11^{\text {th }}$ & $20 / 12$ to $16 / 01 / 2017$ & - & $23 / 11$ to $13 / 12 / 2016$ & - \\
\hline $12^{\text {th }}$ & $17 / 01$ to $13 / 02 / 2017$ & - & $14 / 12$ to $01 / 04 / 2017$ & - \\
\hline $13^{\text {th }}$ & - & - & $05 / 01$ to $25 / 01 / 2017$ & - \\
\hline $14^{\text {th }}$ & - & - & $26 / 01$ to $15 / 02 / 2017$ & - \\
\hline
\end{tabular}


tion of canopy light interception (LI) and leaf area index (LAI), similar to the study made by Geremia et al. (2018), with Brachiaria brizantha cv. Piatã.

The duration of each growth-and-cutting cycle (CC) was different for each cropping system, as well as the total number of cycles, depending on the $\mathrm{CC}$ of each one. For the winter forages, the experimental period depended on the persistence of black oat and ryegrass in the field which varied in both the intercropped Guinea grass and Bermuda grass. During the experimental period, the lowest recorded temperature was $3.0^{\circ} \mathrm{C}$, as shown in Figure 1.

The plots were irrigated with a conventional sprinkle irrigation system, with sprinklers spaced $12 \mathrm{~m}$ $\times 12 \mathrm{~m}$ (emitters $\times$ lines) apart, equipped with a sectorial device to restrict irrigation to an angle of $90^{\circ}$. The sprinklers operated at a pressure of $250 \mathrm{kPa}$, with a flow rate of $0.492 \mathrm{~m}^{3} \mathrm{~h}^{-1}$ and water application rate (Wa) of $12.3 \mathrm{~mm} \mathrm{~h}^{-1}(10 \%$ evapotative losses estimated by Christiansen coefficient. Irrigation time varied, according to the crop water consumption as measured in the lysimeters.

A pre-established irrigation interval was determined in order to maintain the soil moisture content (SMC) higher than $70 \%$ of the moisture content between field capacity $\left(\theta_{f c}\right)$ and wilting point $\left(\theta_{w p}\right)\left(\mathrm{SMC} \geq 0.7\left[\theta_{f c}-\right.\right.$ $\left.\left.\theta_{w p}\right]\right)$. This limit is above that recommended by Fonseca et al. (2007) for pasture irrigation management (SMC = $\left.0.5\left[\theta_{f c}-\theta_{p w p}\right]\right)$, in order to keep the soil water readily available for the crops. Therefore, the maximum soil water consumption was $25 \mathrm{~mm}$. The irrigation water depth (LI) applied was determined by the ETc measured by the lysimeters. Volumetric soil moisture at field capacity $\left(\theta_{f c}\right)$ considered corresponded to the soil water matric poten- tial $\Psi_{m}=10 \mathrm{kPa}$, according to Benevenute et al. (2016). Current soil moisture $\left(\theta_{c}\right)$ as a function of $\Psi_{m c}$ (current soil water matric potential) was calculated by mean values of the soil water retention curve, obtained from a tension table and by a Richards extractor, in a laboratory of soil and water quality analyses adjusted by the van Genuchten equation (van Genuchten, 1980):

$\theta_{c}=0.2938+\left[\frac{(0.4934-0.2938)}{\left[1+\left(0.113 \psi_{m c}\right)^{1.3211}\right]^{0.2431}}\right] ;$

$\left(\mathrm{R}^{2}=1.00\right.$ and $\left.p<0.01\right)$

$\theta_{r}=0.2938 \mathrm{~cm}^{3} \mathrm{~cm}^{-3} ; \theta_{s}=0.4934 \mathrm{~cm}^{3} \mathrm{~cm}^{-3} ;$

in which:

$\theta_{c}=$ current volumetric soil moisture $\left(\mathrm{cm}^{3} \mathrm{~cm}^{-3}\right)$;

$\theta_{r}=$ residual volumetric soil moisture $\left(\mathrm{cm}^{3} \mathrm{~cm}^{-3}\right)$;

$\theta_{s}=$ volumetric soil moisture at the saturation point $\left(\mathrm{cm}^{3} \mathrm{~cm}^{-3}\right)$;

$\Psi_{m c}=$ current soil water matric potential $(\mathrm{kPa})$.

The reference evapotranspiration (ETo) was calculated from the combined data of three automatic weather stations. The main source of data was an automatic weather station located $50 \mathrm{~m}$ from the area of the experi-

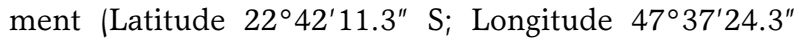
$\mathrm{W})$. To cover data fails, we used data from a second automatic weather station, placed in the same place as the first weather station. Lastly, in one case of data fail, we used data from another automatic weather station located $2,205 \mathrm{~m}$ from the experimental area (Latitude $22^{\circ} 42^{\prime} 01.1^{\prime \prime} \mathrm{S}$; Longitude $\left.47^{\circ} 38^{\prime} 39.8^{\prime \prime} \mathrm{W}\right)$. The meteoro-

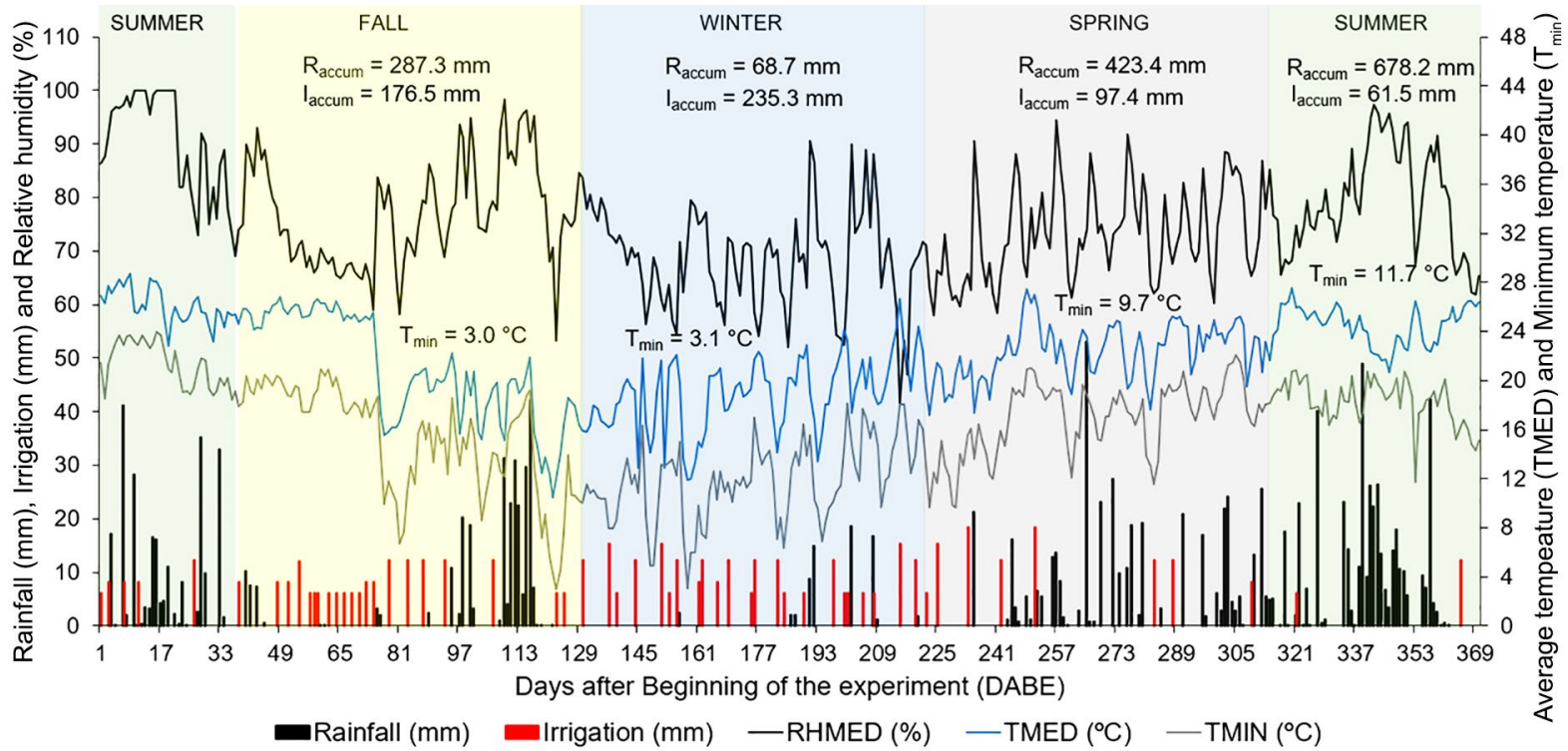

Figure 1 - Rainfall values $(\mathrm{mm})$, relative humidity $(\%)$, minimum temperature $\left({ }^{\circ} \mathrm{C}\right)$ and average temperature $\left({ }^{\circ} \mathrm{C}\right)$ during the experimental period, from 02/2016 to 02/2017. Piracicaba/SP; Raccum = accumulated rainfall in the period; laccum = accumulated irrigation in the period; Tmin $=$ lowest temperature presented in the period. 
logical data observed were processed using the software Reference Evapotranspiration Calculator program, and the Penman-Monteith equation based on the methodology proposed by FAO 56 (Allen et al., 1998).

Since the data were used on an hourly scale, the original equation as modified by Allen et al. (2006), changed the coefficients of the numerator $(\mathrm{Cn}=37)$ and the denominator, according to the surface resistance $(\mathrm{Sr})$ $(\mathrm{Cd}=0.24$ for $\mathrm{Sr}>0$ and 0.96 for $\mathrm{Sr} \leq 0)$, as represented in equation 2 :

$$
\text { ETo }=\frac{0.408 s(R b-G)+\frac{\gamma C_{n} U_{2}(e s-e a)}{T+273}}{s+\gamma\left(1+C_{d} U_{2}\right)}
$$

in which:

ETo - reference evapotranspiration $\left(\mathrm{mm} \mathrm{d}^{-1}\right)$;

$R b$ - net radiation at the crop surface $\left(\mathrm{MJ} \mathrm{m}^{-2} \mathrm{~d}^{-1}\right)$;

$\mathrm{G}$ - soil heat flux density $\left(\mathrm{MJ} \mathrm{m}^{-2} \mathrm{~d}^{-1}\right)$;

$\gamma$ - psychrometric constant $\left(0.063 \mathrm{kPa}{ }^{\circ} \mathrm{C}^{-1}\right)$;

$U_{2}$ - wind speed at $2 \mathrm{~m}$ high $\left(\mathrm{m} \mathrm{s}^{-1}\right)_{i}$

es - saturation vapor pressure $(\mathrm{kPa})$;

$e a-$ actual vapor pressure $(\mathrm{kPa})$;

$T$ - mean daily air temperature $\left({ }^{\circ} \mathrm{C}\right)$;

$s$ - slope vapor pressure curve based on air temperature $\left(\mathrm{kPa}{ }^{\circ} \mathrm{C}^{-1}\right)$.

$s=\frac{4098 s}{(T+237.3)^{2}}$

The choice of the ETo method is justified by its robustness and accuracy (Valiantzas, 2013). Furthermore, Pereira et al. (2014) used different methods to estimate the ETc of Paspalum notatum Flügge, in Piracicaba, SP, and observed that the PM-FAO 56 method revealed the highest agreement $\left(R^{2}=0.94\right)$ with the field measurements of ETo.

Weighing lysimeters were used to determine the crop evapotranspiration (ETc), each one comprising a rigid PVC circular box, $500 \mathrm{~L}$ in volume, top diameter of $1.22 \mathrm{~m}$, bottom diameter less than $1.0 \mathrm{~m}$, and a height of $0.6 \mathrm{~m}$. Each lysimeter has a weighing system and a drainage and water collection system, both with load cells surrounded by a brickwork structure in the ground.

The weighing system of the lysimeter had three load cells arranged in a metallic, triangular shaped structure circumscribed to the circumference of the lysimeter. The drainage system comprised a plastic recipient and a drainage valve, with a load cell automatically driven by a solenoid valve. Sanches et al. (2017a) described further details of the drainage system.

The crop evapotranspiration (ETc) was calculated by the water balance (inputs and outputs), obtained through the daily weight difference of the lysimeter system, according to the following equation:

$E T c=V_{s}+R+I-V_{d}$ in which:

ETC - crop evapotranspiration $\left(\mathrm{mm} \mathrm{d}^{-1}\right)$;

$V_{s}$ - storage variance $\left(\mathrm{mm} \mathrm{d}^{-1}\right)$;

$R$ - rainfall $\left(\mathrm{mm} \mathrm{d}^{-1}\right)$;

$I$ - irrigation $\left(\mathrm{mm} \mathrm{d}^{-1}\right)$;

$V_{d}$ - drainage variance $\left(\mathrm{mm} \mathrm{d}^{-1}\right)$;

Daily values of crop evapotranspiration (ETc) and reference evapotranspiration (ETo) obtained were used to calculate the crop coefficient values $(\mathrm{Kc})$ for the forages throughout the collection cycles (regrowth), according to equation 5 :

$K_{c}=\frac{E T_{c}}{E t_{o}}$

in which:

$K c$ - crop coefficient (non-dimensional);

$E T C$ - crop evapotranspiration $\left(\mathrm{mm} \mathrm{d}^{-1}\right)$;

ETo - reference evapotranspiration $\left(\mathrm{mm} \mathrm{d}^{-1}\right)$

The results were processed using an MS Excel ${ }^{\otimes}$ spreadsheet, in a quantitative description analysis. The mean Kc data were calculated on a 3-day scale for the exclusive and overseeded Bermuda grass, and on a 4-day scale for the exclusive and overseeded Guinea grass, due to their respective mean cycles of 21 and 28 days, in order to use multiple numbers from each crop growing cycle.

We produced a set of statistical analyses of the Kc data obtained in the two treatments (single cropped $\times$ overseeded cropping), divided into four (4) steps, as follows:

1) Separation of the data by season (autumn; winter; spring), in order to detect differences in Kc between seasons. After, we grouped the data of all the period of overseeded cropping (autumn + winter + early spring) in order to detect differences in Kc for all the experimental period.

2) Anderson-Darling test, applied to verify if the data fitted the Normal Distribution.

3) F-test for variances, in order to detect possible differences between them (Single cropping versus overseeded cropping), and after, to select tests adequate for the next step.

4) Two sample T-tests, in order to verify if there were differences in Kc data, comparing the two treatments (single cropping versus overseeded cropping). The F-test for variances allowed for selecting between a T-test for equivalent variances and a T-test for different variances.

\section{Results}

\section{Statistical analyses}

The results obtained by the Anderson-Darling test assured that all the data fitted the normal distribution. Thus, no data transformation was required.

The F-test for variances resulted in differences ( $p<0.05$, and even $p<0.01$ in many tests) between 
treatments (single cropping versus overseeded cropping), except for Guinea grass cv. 'Mombaça' in autumn $(p=0.33)$, and Cynodon in spring $(p=0.18)$. The statistical tests also allowed us to select the T-test for equivalent or different variances. The T-test for equivalent variances was used on 'Mombaça' in autumn and on Cynodon spp. in early spring. We used the T-test for different variances on 'Mombaça' and Cynodon spp., in all the other periods.

The T-test results for equivalent variances was applied to Kc data of Guinea grass cv. 'Mombaça in autumn, and Kc data of Cynodon spp. in early spring, resulting in no significant differences between Kc data (Single cropped versus Overseeded cropped) for 'Mombaça' in autumn $\left[\mathrm{P}_{(\mathrm{T}<=\mathrm{t})}=0.40\right]$ and Cynodon spp. treatments in early spring $\left[\mathrm{P}_{(\mathrm{T}<=\mathrm{t})}=0.18\right]$.

The T-test for different variances was applied to Kc data from both the grasses in all the other periods ('Mombaça' in winter and autumn + winter; Cynodon spp. in autumn, winter, and autumn + winter + early spring). The results showed no significant differences in Kc data between the treatments (single cropped versus overseeded cropped), for 'Mombaça' in winter $\left[\mathrm{P}_{(\mathrm{T}<=\mathrm{t})}\right.$ $=0.93]$ and autumn + winter $\left[\mathrm{P}_{(\mathrm{T}<=\mathrm{t})}=0.70\right]$. Similarly there were no differences in Kc values for Cynodon spp. in autumn $\left[\mathrm{P}_{(\mathrm{T}<=\mathrm{t})}=0.44\right]$, winter $\left[\mathrm{P}_{(\mathrm{T}<=\mathrm{t})}=0.51\right]$, and autumn + winter + early spring $\left[\mathrm{P}_{(\mathrm{T}<-\mathrm{t})}=0.15\right]$.

\section{ETc, ETo and Kc for single cropped Guinea grass (Megathyrsus maximus cv. Mombaça)}

During the experimental period, Guinea grass had mean values of $\mathrm{Kc}=1.07$ and $\mathrm{ETc}=3.99$. During fall and winter, the mean values of Kc were 1.08 and 1.10, respectively (Figure 2). At the beginning of the cycle (the first three days), Kc values were lower than 1, obtaining mean values of 0.81 and 0.76 , for fall and winter, respectively, at the beginning of the cycles (Figure 2).

The accumulated ETo in the fall/winter season was approximately $760 \mathrm{~mm}$, with a rainfall depth of 356 $\mathrm{mm}$ and an irrigation water depth of $411.8 \mathrm{~mm}$, totaling $767.8 \mathrm{~mm}$. Thus, $54 \%$ of the total water consumption came from irrigation. The predicted ETc for the whole period was $797.3 \mathrm{~mm}, 30 \mathrm{~mm}$ higher than the water input in the system (irrigation + rainfall).

In the three cycles during the fall, the accumulated ETc was $435.6 \mathrm{~mm}$, and the daily dry matter forage accumulation $136.9 \mathrm{~kg} \mathrm{ha}^{-1} \mathrm{~d}^{-1}$, with a mean leaf area index (LAI) of 5.3 at the end of the cycle. During the winter season, the accumulated ETc was $295.1 \mathrm{~mm}$, daily dry matter forage accumulation was $118.1 \mathrm{~kg} \mathrm{ha}^{-1}$ $\mathrm{d}^{-1}$, with a mean LAI of 4.8 at the end of the cycle.

In Figure 3, ETc, ETo and Kc values for the Guinea grass during spring/summer seasons were reported as being $4.21 \mathrm{~mm}$ and $3.77 \mathrm{~mm} \mathrm{~d}^{-1}$ in spring, and 4.05 and $4.40 \mathrm{~mm} \mathrm{~d}^{-1}$ in summer, respectively. During summer, the Guinea grass reached the highest Kc values, with a general mean of 1.12. In the spring and summer seasons, the total yield of Guinea grass was $33.4 \mathrm{Mg}$ of DM $\mathrm{ha}^{-1}$, corresponding to daily mean forage accumulations of 195.6 and $211.4 \mathrm{~kg}$ of dry matter ha $\mathrm{h}^{-1} \mathrm{~d}^{-1}$, respectively during spring and summer. The mean values of LAI at the end of the spring and summer cycles were 6.6 and 6.7 , respectively.

In the spring/summer seasons, accumulated rainfall was $1101.6 \mathrm{~mm}$ (Figure 1), corresponding to $76 \%$ of total rainfall in the year, with accumulated ETo and ETc of 677 and $671 \mathrm{~mm}$ (Figure 3), respectively. Despite the lower evapotranspiration in relation to water input

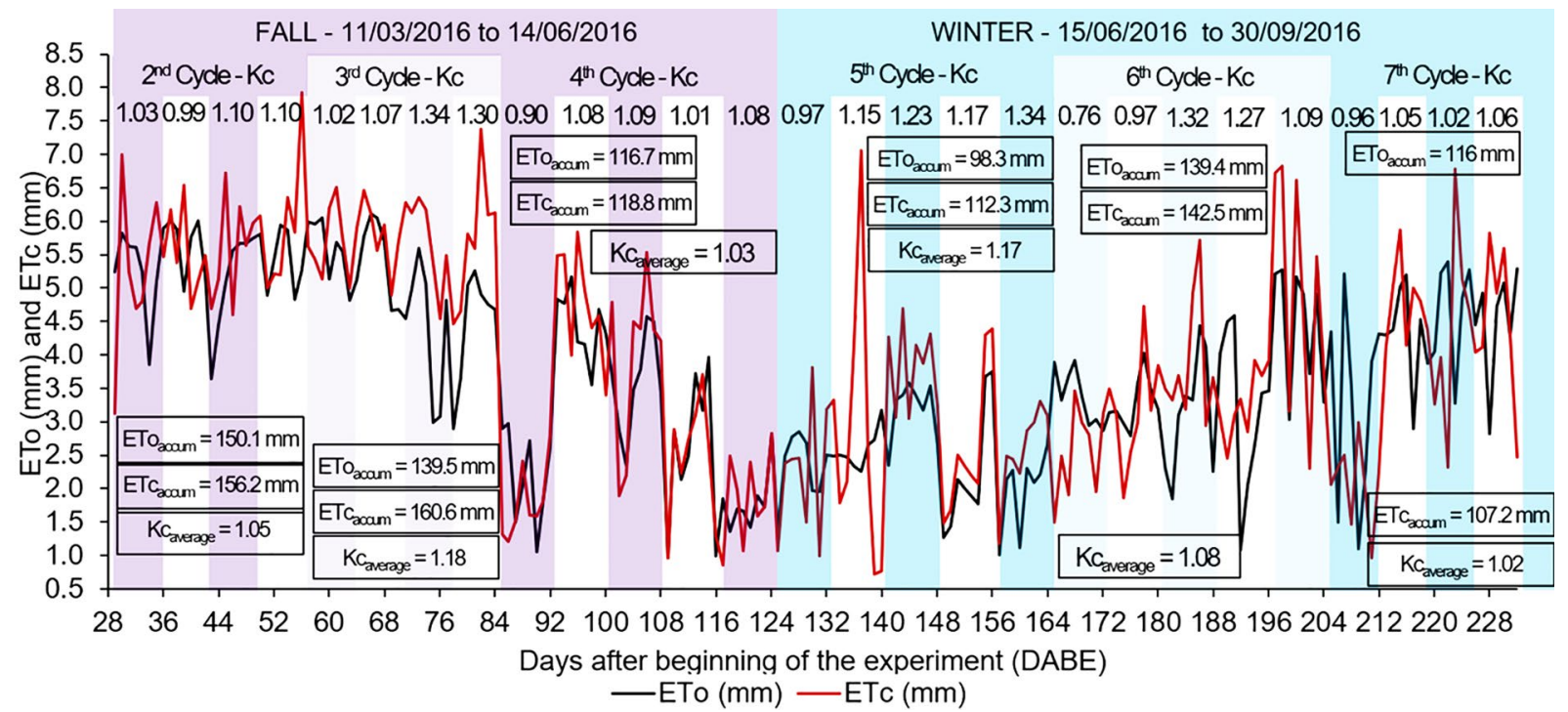

Figure 2 - ETc, ETo and Kc values for the single cropped Guinea grass (Megathyrsus maximus cv. Mombaça) in the fall/winter seasons. Piracicaba/SP, 2016. ETo ${ }_{\text {accum }}=$ accumulated reference evapotranspiration in the cycle; $\mathrm{ETc}_{\text {accum }}=$ accumulated crop evapotranspiration in the cycle and $\mathrm{Kc}_{\text {average }}=$ average $\mathrm{Kc}$ of the cycle. 
(rainfall + irrigation), there was additional irrigation of $158.9 \mathrm{~mm}$.

ETc, ETo and Kc for the overseeded Guinea grass (Megathyrsus maximus cv. Mombaça) with black oat + ryegrass in the fall/winter seasons

The overseeded crop showed 3.1 and $3.0 \mathrm{~mm} \mathrm{~d}^{-1}$ of ETo and ETc, respectively, with a total duration of the experiment of 140 days corresponding to $433.6 \mathrm{~mm}$ of ETo with $324.6 \mathrm{~mm}$ of rainfall and an irrigation water depth of $284.6 \mathrm{~mm}$ (Figure 1). The mean Kc value was 0.97 (Figure 4).

For all the experimental period, the average LAI at the end of the cycles was 4.29 , and the average daily dry matter accumulation $86.0 \mathrm{~kg} \mathrm{ha}^{-1} \mathrm{~d}^{-1}$.

\section{ETc, ETo and Kc for the single cropped Bermuda} grass (Cynodon spp.)

The Kc data obtained in the winter cycles were close to 1 (Figure 5), while in the fall the ETc values re-

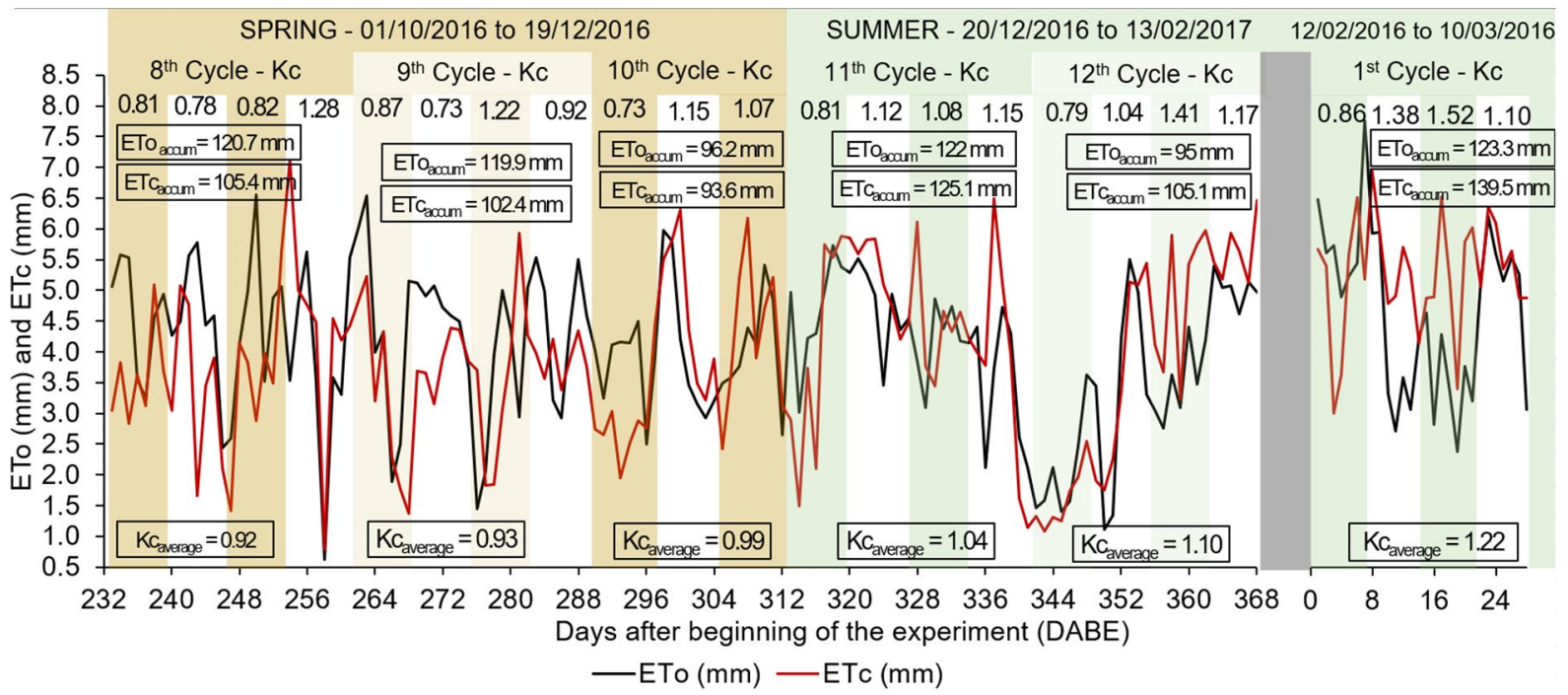

Figure 3 - ETc, ETo and Kc values for the Guinea grass (Megathyrsus maximus cv. Mombaça) in the spring/summer seasons. Piracicaba-SP, 2016/17. $\mathrm{ETO}_{\text {accum }}=$ accumulated reference evapotranspiration in the cycle; $\mathrm{ETC}_{\mathrm{accum}}=$ accumulated crop evapotranspiration in the cycle and $\mathrm{Kc}_{\text {average }}=$ average $\mathrm{Kc}$ of the cycle.

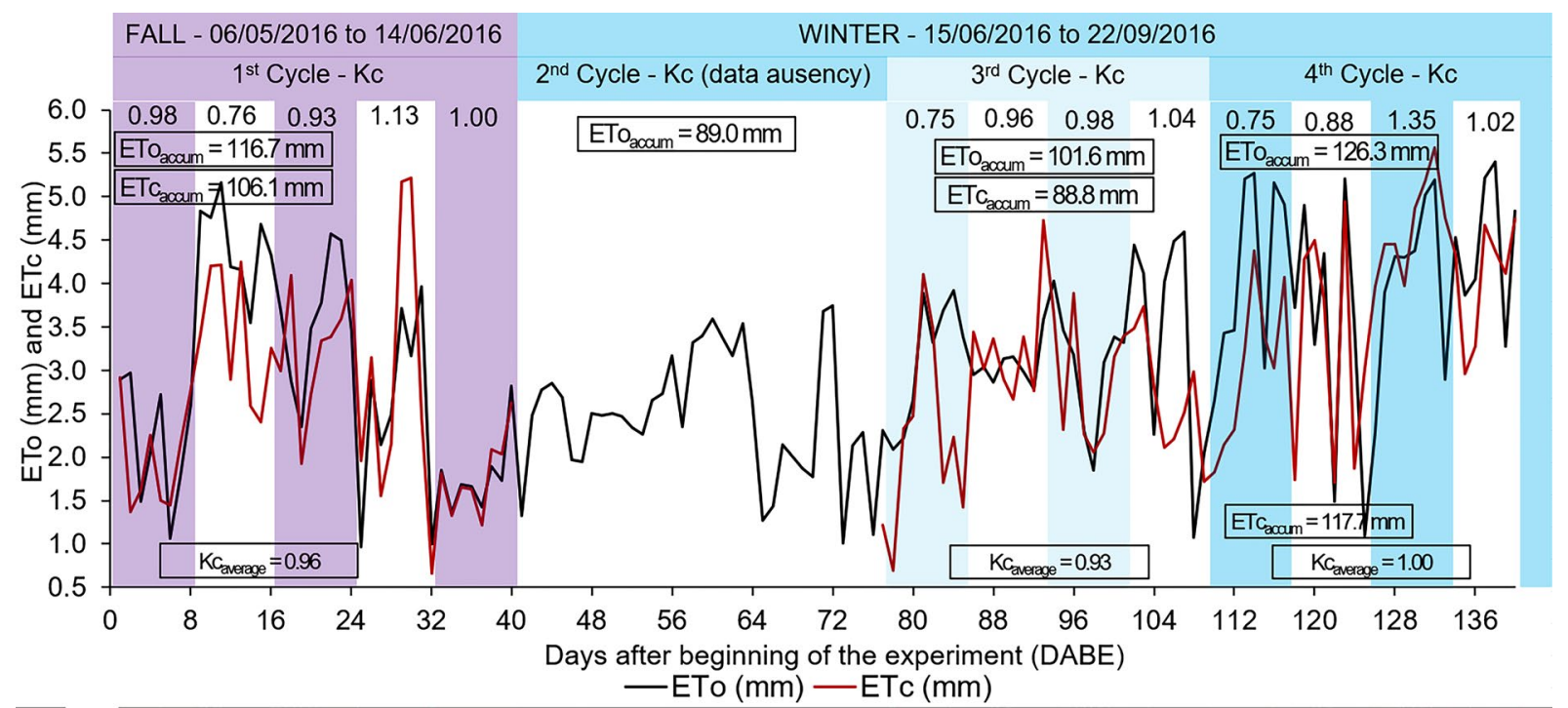

Figure 4 - ETc, ETo and Kc values for the Guinea grass (Megathyrsus maximus cv. Mombaça) overseeded with black oat + ryegrass in the fall/

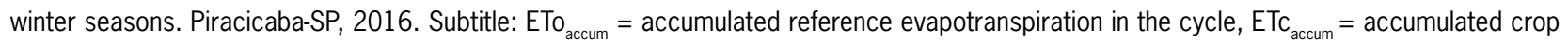
evapotranspiration in the cycle and $\mathrm{K}_{\text {average }}=$ average $\mathrm{Kc}$ of the cycle. 
corded were lower than the ETo, resulting in a mean $\mathrm{Kc}$ value below 1 . The forage crops presented mean values of daily dry matter accumulation of 73.5 and $66.5 \mathrm{~kg}$ $\mathrm{ha}^{-1} \mathrm{~d}^{-1}$ during fall and winter, respectively. The mean end-cycle LAI was 2.5, lower than the one obtained with the single cropped Guinea grass.

During the fall and winter seasons, accumulated rainfall was $354.2 \mathrm{~mm}$ and there was $377.9 \mathrm{~mm}$ due to irrigation. Thus, the crops received a total water depth of $732.1 \mathrm{~mm}$ (Figure 1). The ETo and ETc in these seasons were 623.2 and $555.8 \mathrm{~mm}$, respectively, indicating a probable water surplus of $176.3 \mathrm{~mm}$, which may have been drained through the soil (deep drainage) or suffered runoff.

The daily mean values of ETc during spring and summer were 3.92 and $3.93 \mathrm{~mm} \mathrm{~d}^{-1}$, respectively (Figure 6). During spring, the highest value for daily dry matter accumulation was $113.3 \mathrm{~kg} \mathrm{ha}^{-1} \mathrm{~d}^{-1}$, together with an LAI of 2.9.

During the spring/summer season, the rainfall contributed with $1,101.6 \mathrm{~mm}$, complemented by an irrigation water depth of $192.8 \mathrm{~mm}$, a total water depth of $1,293.6$

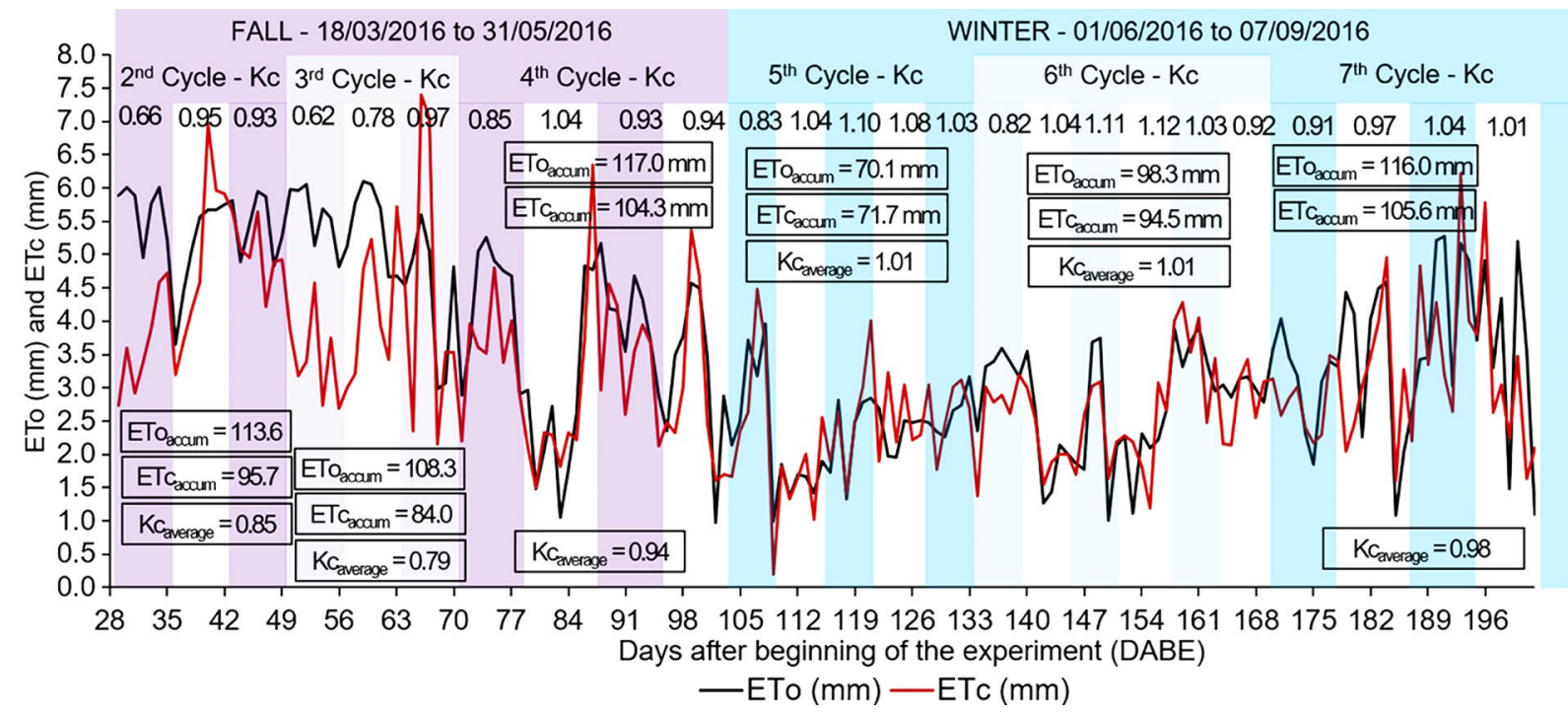

Figure 5 - ETc, ETo and Kc values for the single cropped Bermuda grass (Cynodon spp.) in the fall/winter period. Piracicaba, in the state of Sao Paulo, 2016. $\mathrm{ETo}_{\text {accum }}=$ accumulated reference evapotranspiration in the cycle; $\mathrm{ETc}_{\text {accum }}=$ accumulated crop evapotranspiration in the cycle and $\mathrm{Kc}_{\text {average }}=$ average $\mathrm{Kc}$ of the cycle.

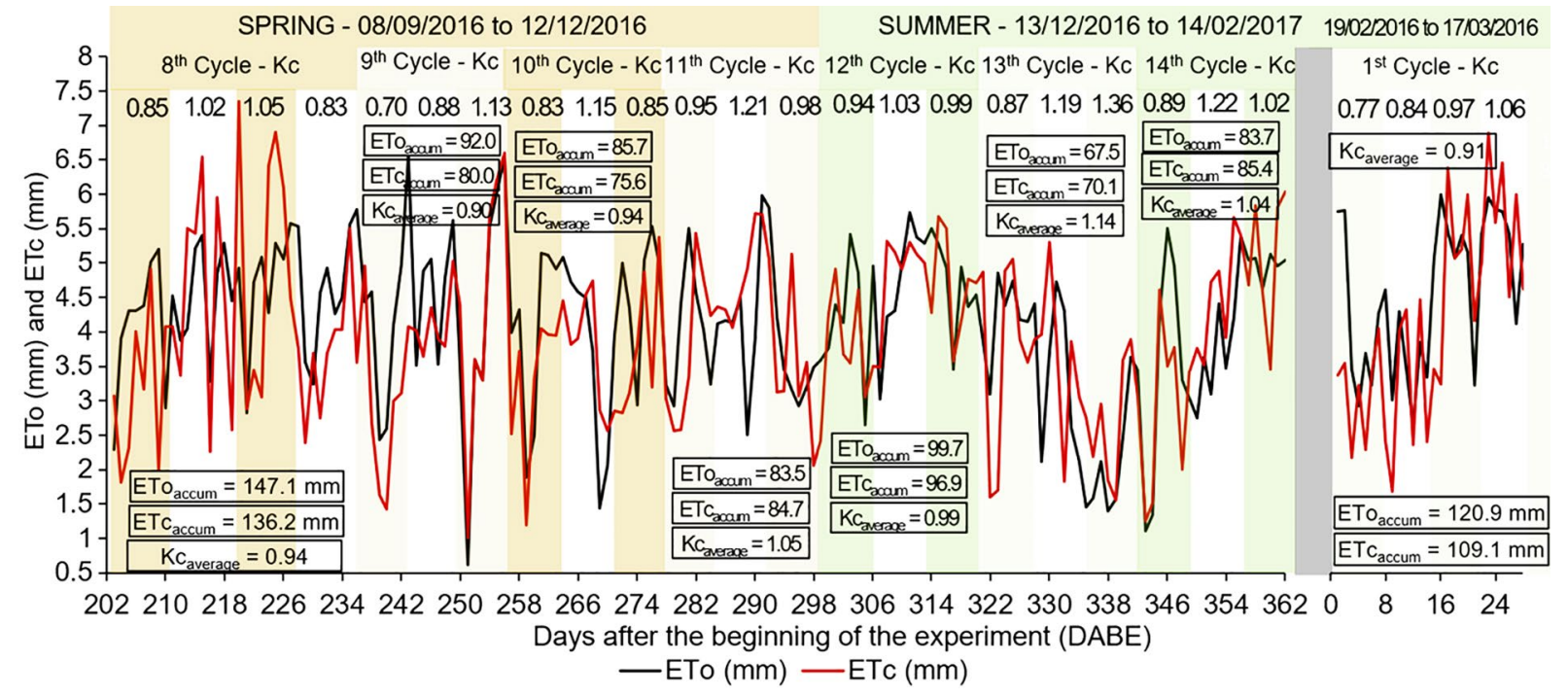

Figure 6 - ETc, ETo and Kc values for Bermuda grass (Cynodon spp.) in exclusive crop in spring/summer, Piracicaba/SP, 2016/17. ETo ${ }_{\text {accum }}=$ accumulated reference evapotranspiration in the cycle; $\mathrm{ETC}_{\text {accum }}=$ accumulated crop evapotranspiration in the cycle and $\mathrm{Kc}_{\text {average }}=$ average $\mathrm{Kc}$ of the cycle. 
mm, much higher than the ETo and ETc values, 780 and $738 \mathrm{~mm}$, respectively. As in fall/winter, there have been runoff and deep drainage, but on a larger scale.

\section{ETc, ETo and Kc for Bermuda grass (Cynodon} spp.) overseeded with black oat + ryegrass during the fall/winter seasons.

As previously occurred with the lysimeter of the intercropped Bermuda grass, black oat and ryegrass (lysimeter 4), the electrical system of lysimeter 4 presented problems due to a storm, with no data from 29/06/2016 to 20/07/2017, as is shown in Figure 7.

During the winter, the forage crops presented mean values of ETc $=2.83 \mathrm{~mm} \mathrm{~d}^{-1}$ and $\mathrm{Kc}=1.04$, and the accumulated ETo was $222.4 \mathrm{~mm}$. During the winter cycles, there was synchronism between the intercropped grasses (Bermuda grass, black oat and ryegrass), with daily dry matter accumulation of $73.6 \mathrm{~kg} \mathrm{ha}^{-1} \mathrm{~d}^{-1}$ and mean, end-cycle LAI of 2.9.

\section{Discussion}

During the experimental period, the water depth available to the crops was $2,028.3 \mathrm{~mm}$, divided between rainfall $(1,457.6 \mathrm{~mm})$ and irrigation $(570.7 \mathrm{~mm})$ (Figure 1). A large drop in temperature in the fall/winter seasons was observed, and there were several days with temperatures below $12{ }^{\circ} \mathrm{C}$, generally indicated as a limit to the growth of tropical grasses (Andrade et al., 2016), which limited the growth of Bermuda and Guinea grasses.

The spring/summer seasons received $76 \%$ of the total rainfall (Figure 1), with a mean air temperature of $23.8^{\circ} \mathrm{C}$, approximately $4{ }^{\circ} \mathrm{C}$ above the fall/winter mean temperature. This corroborates the assumption of forage yield seasonality (Antoniel et al., 2016; Durante et al., 2017; Sanches et al., 2017b), which normally occurs during the fall/winter in the Brazilian southeast region, due to limitations of temperature and photoperiod.

In the fall/winter seasons, the ETc of Guinea grass surpassed the water input in the system by $30 \mathrm{~mm}$, a fact that may bear a close relationship to soil moisture during the early days of fall and the last days of winter. Since the soil water balance was cumulative, in the start of spring, there may have been a soil water deficit, soon met by irrigation. Furthermore, Benevenute et al. (2016) claim attention is necessary to avoid errors when managing the soil moisture.

Notwithstanding, in the spring/summer seasons, ETo and ETc of Guinea grass were lower than the rainfall (Figure 1 and Figure 3). Yet, there was irrigation in the period, because the rainfall distribution was not homogeneous and regular, providing subsurface drainage throughout spring and summer. Bilibio et al. (2017) observed that the ETc of perennial grasses was $70 \%$ of annual rainfall, and there was drainage of 271.2 and 192.1 $\mathrm{mm}$ in 2014 and 2015, respectively.

In Guinea grass growth cycles, Kc values during the spring were close to 1 in the first 7-10 days, with values lower than 1 in some cases, such as in cycles \#8 and \#9, (Figure 3). During these cycles there were Kc peaks around 1.2, between 14 and 21 days, in fall/winter (Figure 2), and around 1.5 in the first summer cycle (Kc = 1.52; Figure 3).

The post-cut height (residue) for Guinea grass was $30 \mathrm{~cm}$, according to Euclides et al. (2016). In the first few days, soil exposure to sunlight was evident with minor presence in the leaf area, considering that it is grass with cespitose habit (clumps) and fast growth. The peak

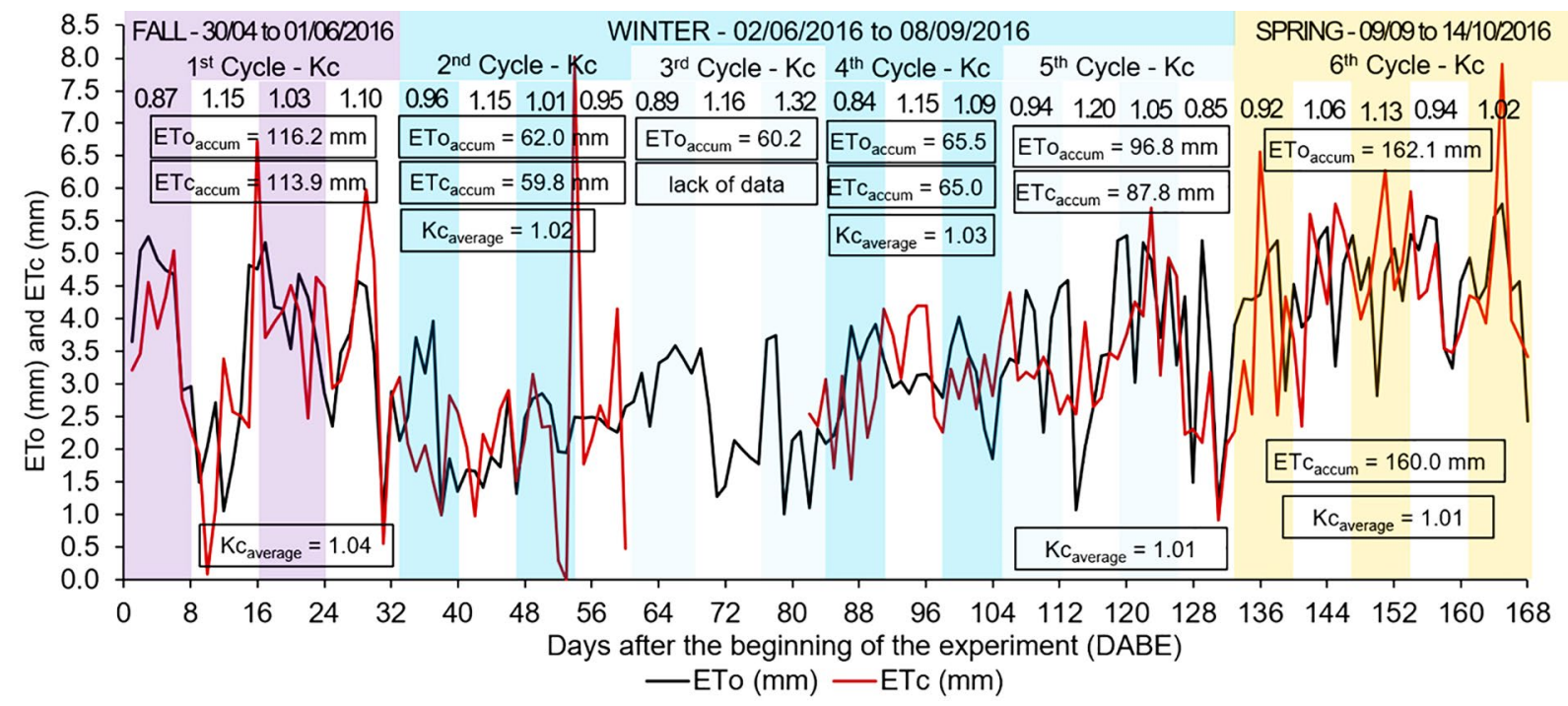

Figure 7 - ETc, ETo and Kc values for Bermuda grass (Cynodon spp.) overseeded with black oat + ryegrass, Piracicaba/SP, 2016. ETo ${ }_{\text {accum }}=$ accumulated reference evapotranspiration in the cycle; $\mathrm{ETC}_{\text {accum }}=$ accumulated crop evapotranspiration in the cycle and $\mathrm{Kc}_{\text {average }}=$ average $\mathrm{Kc}$ of the cycle. 
of photosynthesis is reached in 7 to 10 days after the cut with a high concentration of leaves, covering the exposed soil before then.

Barbosa et al. (2015) worked with Megathyrsus maximus cv. Tanzania and observed that the Kc started at 0.64 , and reached 1.20, from the first day of the cycle to 30 days after the cut, respectively. Antoniel et al. (2016) determined Kc values for 'Mombaça' Guinea grass with cut intervals of 30-40 days, at Cidade Gaúcha, in the state of Parana and verified that the Kc reached 1.33 at the end of the cycle.

In most of the Guinea grass cycles, the Kc during the experimental year underwent growth that had characteristics of a quadratic function (i.e. similar to those of a quadratic function), as seen in cycles $1,3,6,9,10,11$ and 12 . These results are similar to those obtained by $\mathrm{Li}$ et al. (2008), that observed the Kc at one-day intervals, with regrowth cycles of 120 days, reporting fast growth to 60 days and a prompt decline after that time. According to these authors, the Kc minimum and Kc maximum values were 0.15 and 1.85 , respectively.

The cycles of Guinea grass overseeded with black oat + ryegrass began at the end of fall/the start of winter, when there were problems due to a storm that made it impossible to measure the corresponding ETc of the whole season. However, ETo was lower than the total water input (rainfall + irrigation) in $175.6 \mathrm{~mm}$ (Figure 1), without water deficit.

Probably the intercropping among Guinea grass 'Mombaça', black oat and ryegrass did not present synergism, as there was some competition between the forage species, probably with an effect of allelopathy. During the intercropping period of Guinea grass with black oat + ryegrass, the residue height (post-cut) was reduced to $15 \mathrm{~cm}$, in order to ease germination and development of winter forages. However, it was observed that there was a threat to the growth of the Guinea grass, which reflected water consumption (Figure 4). The accumulated ETc during the winter season was always lower than the ETo, unlike that occurring in the single cropped Guinea grass, which showed higher intakes in cycles 5 and 6 during winter. Thus, black oat and ryegrass practically did not contribute to increases in water consumption. This is associated with the lower mean value of LAI of the intercropped forage crops in relation to the single cropped tropical forage crops, as well as being associated with their dry matter production during the cycles.

The interaction between Guinea grass and winter forages was not synergistic and caused negative effects in both water intake and the forage dry matter production. The literature indicates several studies with overseedings of winter forages in tropical pastures, but most were made with Bermuda grasses (Gomes et al., 2015; Sanches et al., 2015). In these works, the authors observed significant morphogenic differences; in particular, Sanches et al. (2015) found that the dry matter production in the overseeded cultivation was higher than in the single cropped, with a mean dry matter increase of $540 \mathrm{~kg}$ per cycle.
In the first three crop cycles, the single cropped Bermuda grass (Cynodon spp.) showed irregular and low values of water consumption (ETc) (Figures 5 and 6). The grass was implanted with seedlings, being a newly established crop in the area in the final period of formation, and this marked the beginning of nitrogen fertilization for each cycle. Therefore, it is possible that the results obtained were a response to adjustments in the crop management.

In the fourth cycle, evapotranspiration of Bermuda grass presented behavior similar to ETo. During the experimental cycle, the grass had an accumulated ETc of $1,293.8 \mathrm{~mm}$, while ETo was $1,403.2 \mathrm{~mm}$. The mean $\mathrm{Kc}$ of the whole period was equal to 0.96 . On the other hand, Santana et al. (2016) worked with Cynodon spp. cv. Tifton 85, in Uberaba-MG, and observed an average Kc of 1.07, with mean values of ETc and ETo of 3.62 and $3.34 \mathrm{~mm} \mathrm{~d}^{-1}$, respectively. However, when compared to 'Mombaça' Guinea grass, the Bermuda grass presented a lower yearly dry matter yield (30.2 $\mathrm{Mg} \mathrm{ha}^{-1} \mathrm{yr}^{-1}$ for Bermuda grass, and $59.1 \mathrm{Mg} \mathrm{ha}^{-1} \mathrm{yr}^{-1}$ for Guinea grass). This may have led to a mean Kc value lower than one. Whatsmore, evapotranspiration is directly proportional to the growth, photosynthesis and the dry matter productivity of pastures, considering their water use efficiency (Eichelmann et al., 2016).

Working with Bermuda grass (Cynodon spp.) during the formation period, Sanches et al. (2017b) obtained a mean Kc value of 0.99 , but it varied during the initial period of growth. The same authors observed that, in both Bermuda grass and Guinea grasses (Megathyrsus maximus cv. Mombaça), Kc varied throughout the cycles. This endorsed the view that different values of Kc should be adopted during the growth stage of grasses (Sanches et al., 2017b).

For both the grasses, Guinea grass and Bermuda grass, no distinct values of Kc were observed, according to season. ETc and ETo decreased in the winter, therefore, as $\mathrm{Kc}$ is a ratio between both, there was no significant variation in the values obtained in each season. However, crop water consumption decreased, as daily ETc decreased in the fall/winter seasons (Figures 2 and 5). Wagle el al. (2017) stated that the seasonal variation is dependent on the solar radiation available in the period.

The intercropped Bermuda grass overseeded with black oat and ryegrass showed good synergism, causing the winter cycles to be shortened due to the rapid growth of black oat and ryegrass. Thus, there were two cycles of gathering (collection) more than in the intercropped Guinea grass, because the winter forages survived in the area until the first week of Oct. Sanches et al. (2015) also obtained prolonged yields of winter forage crops for black oat overseeded in Cynodon spp. cv. Tifton 85, with yields until early Nov, when the main grass suppressed the black oat.

The intercropped Bermuda grass showed ETc close to the ETo, which led to Kc values close to one. The 
characteristics of this intercropping may have contributed to these values, since these grasses are small in size and covered all the soil, similar to Paspalum notatum, which is the grass used as the standard when measuring ETo (Pereira et al., 2014).

In the fifth cycle of single cropped Guinea grass (Figure 2) and the second cycle of Bermuda grass overseeded with black oat and ryegrass (Figure 7), the difference between ETo and ETc was very evident. ETc rose abruptly, and then fell rapidly. Marin et al. (2016) observed a similar fact working with three crops (citrus, coffee and sugar cane). According to the authors, when there are high values ETo, the Kc of these crops decreases abruptly, a phenomenon known as 'crop decoupling' whereby ETc is inversely proportional to ETo, restricting the crop water loss due to the increase in stomatal and atmospheric resistance.

Finally, this study may present uncertainties in certain data, especially when working with data computed in periods with strong changes in climatic elements (winds, storms, and temperature). Although the determination of ETc may seem relatively simple, there are still difficulties related to the practical aspects of its measurement and prediction, and therefore to the complexity in presenting a solution that is fully satisfactory (Allen et al., 2011b).

\section{Conclusions}

Cultivated forage crops can present high water consumption throughout their growth cycle with Kc values above one. Thus, it is not sufficient to adopt a single Kc value for pastures, since it has a large spectrum throughout the cycle.

Even if several authors reported that Kc values were not constant during different stages of crop growth, for pasture crops we propose the use of average values of Kc due to the characteristics of rotational grazing. In this kind of grazing system, a newly grazed paddock (minimum LAI) is next to another for maximum vegetative growth (maximum LAI), to be grazed the next day.

Single cropped Guinea grass presented the highest water consumption and, consequently, the highest Kc values, which reached 1.51. During the experimental period, the Guinea grass overseeded with black oat and ryegrass presented mean Kc values lower than the same single cropped grass.

The single cropped Bermuda grass showed a mean Kc value close to 1 , and the highest peaks occurred in summer, with Kc reaching 1.32. The Bermuda grass overseeded with black oat and ryegrass presented higher Kc values in the winter than the single cropped one.

There was no distinct behavior of Kc values in the fall/winter and spring/summer seasons. However, ETc was always higher in spring/summer than in fall/winter. Thus, crop water consumption varies according to their development, but may also vary according to the climate of each season of the year.
The intercropped Guinea grass + black oat + ryegrass did not show a high ETc during winter, with a mean Kc value lower than the same single cropped grass. In contrast to this, the intercropped Bermuda grass + black oat + ryegrass had a higher mean Kc value than the single cropped Bermuda grass.

\section{Acknowledgments}

To the Fundação de Amparo à Pesquisa do Estado de São Paulo (FAPESP), for the aid granted to the regular research project $n^{\circ} 2012 / 23002-6$.

\section{Authors' Contributions}

Conceptualization: Mendonça, F.C.; Gomes, E.P.; Sanches, A.C. Data acquisition: Sanches, A.C.; Souza, D.P.; Jesus, F.L.F. Data analysis: Sanches, A.C.; Souza, D.P.; Jesus, F.L.F.; Mendonça, F.C. Design of methodology: Sanches, A.C.; Souza, D.P.; Jesus, F.L.F.; Mendonça, F.C. Writing and editing: Sanches, A.C.; Souza, D.P.; Jesus, F.L.F.; Mendonça, F.C.; Gomes, E.P.

\section{References}

Allen, R.G.; Pereira, L.S.; Howell, T.A.; Jensen, M.E. 2011a. Evapotranspiration information reporting. II. Recommended documentation. Agricultural Water Management 98: 921-929.

Allen, R.G.; Pereira, L.S.; Howell, T.A.; Jensen, M.E. 2011 b. Evapotranspiration information reporting. I. Factors governing measurement accuracy. Agricultural Water Management 98: 899-920.

Allen, R.G.; Pereira, L.S.; Raes, D.; Smith, M. 1998. Crop Evapotranspiration: Guidelines for Computing Crop Water Requirements. FAO, Rome, Italy. (FAO Irrigation and Drainage Paper, 56).

Allen, R.G.; Pruitt, W.O.; Wright, J.L.; Howell, T.A.; Ventura, F.; Snyder, R.; Itenfisu, D.; Steduto, P.; Berengena, J.; Yrisarry, J.B.; Smith, M.; Pereira, L.S.; Raes, D.; Perrier, A.; Alves, I.; Walter, I.; Elliott, R. 2006. A recommendation on standardized surface resistance for hourly calculation of reference ETo by the FAO56 Penman-Monteith method. Agricultural Water Management 81: 1-22.

Alvares, C.A.; Stape, J.L.; Sentelhas, P.C.; Gonçalves, J.L.M.; Sparovek, G. 2013. Köppen's climate classification map for Brazil. Meteorologische Zeitschrift 22: 711-728.

Andrade, A.S.; Santos, P.M.; Pezzopane, J.R.M.; Araujo, L.C.; Pedreira, B.C.; Pedreira, C.G. S.; Lara, M.A.S. 2016. Simulating tropical forage growth and biomass accumulation na overview of model development and application. Grass and Forage Science 71: 54-65.

Antoniel, L.S.; Prado, G.; Tinos, A.C.; Beltrame, G.A.; Almeida, J.V.C.; Cuco, G.P. 2016. Pasture production under different irrigation depths. Revista Brasileira de Engenharia Agrícola e Ambiental 20: 539-544.

Barbosa, B.D.S.; Oliveira, F.G.; Figueiredo, F.P. 2015. Determination of crop coefficient $(\mathrm{Kc})$ of Tanzania grass irrigation in General Mines North. Irriga, Edição Especial: 1120 (in Portuguese, with abstract in English). 
Benevenute, P.A.N.; Passos, L.A.C.; Melo, L.B.B.; Silva, É.A.; Oliveira, G.C. 2016. Synthetic polymers on water retention and pore distribution in a clayey Latosol. Revista Scientia Agraria 17: 24-30.

Bilibio, C.; Schellert, C.; Retz, S.; Hensel, O.; Schmeisky, H.; Uteau, D.; Peth, S. 2017. Water balance assessment of different substrates on potash tailings piles using non-weighable lysimeters. Journal of Environmental Management 196: 633643.

Durante, M.; Piñeiro, G.; Irisarri, J.G.N.; Oesterheld, M. 2017. Primary production of lowland natural grasslands and upland sown pastures across a narrow climatic. Ecosystems 20: 543552.

Eichelmann, E.; Wagner-Riddle, C.; Warland, J.; Deen, B.; Voroney, P. 2016. Evapotranspiration, water use efficiency, and energy partitioning of a mature switchgrass stand. Agricultural and Forest Meteorology 217: 108-119.

Euclides, V.P.B.; Lopes, F.C.; Nascimento Junior, D.; Silva, S.C.; Difante, G.S.; Barbosa, R. A. 2016. Steer performance on Panicum maximum (cv. 'Mombaça') pastures under two grazing intensities. Animal Production Science 56: 1849-1856.

Fonseca, A.F.; Melfi, A.J.; Monteiro, F.A.; Montes, C.R.; Almeida, V.V.; Herpin, U. 2007. Treated sewage effluent as a source of water and nitrogen for Tifton 85 bermudagrass. Agricultural Water Management 87: 328-336.

Geremia, E.V.; Crestani, S.; Mascheroni, J.D.C.; Carnevalii, R.A.; Mourão, G.B.; Silva, S.C. 2018. Sward structure and herbage intake of Brachiaria brizantha cv. Piatã in a crop livestockforestry integration area. Livestock Science 212: 83-93.

Gomes, E.P.; Rickli, M.E.; Cecato, U.; Farhate, C.V.V.; Goes, R.H.T.B.; Oliveira, E. 2015. Productivity of Tifton 85 grass irrigated and overseeded with winter forages. Acta Sciencitarium Animal Science 37: 123-128.

Li, S.; Kang, S.; Li, F.; Zhang, L. 2008. Evapotranspiration and crop coefficient of spring maize with plastic mulch using eddy covariance in northwest China. Agricultural Water Management 95: 1214-1222.

Marin, F.R.; Angelocci, L.R.; Nassif, D.S.P.; Costa, L.G.; Vianna, M.S.; Carvalho, K.S. 2016. Crop coefficient changes with reference evapotranspiration for highly canopy-atmosphere coupled crops. Agricultural Water Management 163: 139-145.

Neal, J.S.; Fulkerson, W.J.; Hacker, R.B. 2011. Differences in water use efficiency among annual forages used by the dairy industry under optimum and deficit irrigation. Agricultural Water Management 98: 759-774.
Pereira, A.B.; Villa Nova, N.A.; Pires, L.F.; Angelocci, L.R.; Beruski, G.C. 2014. Estimation method of grass net radiation on the determination of potential evapotranspiration. Meteorological Applications 21: 369-375.

Pereira, L.S.; Allen, R.G.; Smith, M.; Raes, D. 2015. Crop evapotranspiration estimation with FAO56: past and future. Agricultural Water Management 147: 4-20.

Sanches, A.C.; Gomes, E.P.; Rickli, M.E.; Fasolin, J.P.; Soares, M.R.C.; Goes, R.H.T.B. 2015. Productivity and nutritive value of Tifton 85 grass irrigated and overseeding with oats. Revista Brasileira Engenharia Agrícola e Ambiental 19: 126-133 (in Portuguese, with abstract in English).

Sanches, A.C.; Souza, D.P.; Mendonça, F.C.; Maffei, R.G. 2017a. Construction and calibration of weighing lysimeters with an automated drainage system. Revista Brasileira de Engenharia Agrícola e Ambiental 21: 505-509.

Sanches, A.C.; Souza, D.P.; Jesus, F.L.F.; Mendonça, F.C.; Maffei, R.G. 2017b. Water consumption of tropical forage grasses in the period of pasture formation. Revista Brasileira de Agricultura Irrigada 11: 1291-1301 (in Portuguese, with abstract in English).

Santana, M.J.; Wachsmuth, R.; Sgobi, M.A.; Almeida, F.S. 2016. Evapotranspiration and crop coefficient of Tifton-85 in Uberaba, MG. Global Science Technology 9: 39-50 (in Portuguese, with abstract in English).

Valiantzas, J.D. 2013. Simplified forms for the standardized FAO56 Penman-monteuth reference evapotranspiration using limited weather data. Journal of Hidrology 505: 13-23.

Van Genuchten, M.T. 1980. A closed-form equation for predicting the hydraulic conductivity of unsaturated soils. Soil Science Society of America Journal 44: 892-898.

Wagle, P.; Xiao, X.; Gowda, P.; Basara, J.; Brunsell, N.; Steiner, J.; Anup, K.C. 2017. Analysis and estimation of tallgrass prairie evapotranspiration in the central United States. Agricultural and Forest Meteorology 232: 35-47.

Weil, R.R.; Brady, N.C. 2016. The Nature and Properties of Soils. 5ed. Pearson, New York, NY, USA.

Zhang, B.; Kang, S.; Li, F.; Zhang, L. 2008. Comparison of three evapotranspiration models to Bowen ratio-energy balance method for a vineyard in an arid desert region of northwest China. Agricultural and Forest Meteorology 148: 1629-1640.

Zheng, H.; Li, H.; Guo, K. 2012. Calculating methods of forage crop water requirements in pasture. Procedia Engineering 28: 469-475. 